\title{
Bevacizumab in combination with chemotherapy in platinum-sensitive ovarian cancer [Corrigendum]
}

Della Pepa C, Banerjee S. Onco Targets Ther. 2014;7:

1025-1032.

On page 1027, please note that on Table 1, the population for the trial GOG170D (Burger et $\mathrm{al}^{34}$ ) with 62 patients was described as " $\leq 2$ lines of previous treatment, $58 \% \mathrm{Pl}$ resistant, 26\% Pl sensitive with Pl-free interval $<12$ months". However, the correct description of the population should be " $\leq 2$ lines of previous treatment, $58 \% \mathrm{Pl}$ resistant, $42 \%$ $\mathrm{Pl}$ sensitive".

\section{Publish your work in this journal}

OncoTargets and Therapy is an international, peer-reviewed, open access journal focusing on the pathological basis of all cancers, potential targets for therapy and treatment protocols employed to improve the management of cancer patients. The journal also focuses on the impact of management programs and new therapeutic agents and protocols on patient perspectives such as quality of life, adherence and satisfaction. The manuscript management system is completely online and includes a very quick and fair peer-review system, which is all easy to use. Visit http://www.dovepress.com/testimonials.php to read real quotes from published authors. 